\title{
KONSELING KELOMPOK SEBAGAI UPAYA MENINGKATKAN KEMAMPUAN MENGUNGKAPKAN GAGASAN PADA SISWA KELAS VIII ASEMESTER I SMP NEGERI 1 DENPASAR TAHUN PELAJARAN 2016/2017
}

\author{
Gede Erawan \\ SMP Negeri 1 Denpasar
}

\begin{abstract}
ABSTRAK
Latar belakang dari penelitian ini adalah adanya masalah yaitu rendahnya kemampuan mengungkapkan gagasan pada siswa kelas VIII A Semester I SMP Negeri 1 Denpasar, sehingga kondisi tersebut dapat menghambat proses belajar mengajar secara umum. Dengan mengetahui ada permasalahan tersebut maka peneliti ingin mengatasi dengan melaksanakan penelitian melalui konseling kelompok, tujuan penelitian ini adalah melalui konseling kelompok dapat meningkatkan kemampuan mengungkapkan gagasan. Penelitian ini dilaksanakan dalam sistim siklus, hasil tindakan dipantau dengan observasi dan kuesner. Hasil pemantauan deevaluasi secara deskriptif. Hasil evaluasi menunjukan bahwa konseling kelompok dapat meningkatkan kemampuan mengungkapkan gagasan. Berdasarkan data awal adalah 52,50 \% menjadi 75,00 \% setelah dilaksanakan siklus I, Pada siklus II setelah dilakukan penyempurnaan perlakuan dari kekurangan yang ditemukan pada siklus sebelumnya meningkat menjadi $97,50 \%$. pada siklus II ini telah memenuhi indikator keberhasilan yang ditetapkan dan siklus dinyatakan tidak dilanjutkan,Kesimpulan dari penelitian ini bahwa konseling kelompok dapat meningkatkan kemampuan mengungkapkan gagasan pada siswa kelas VIII A Semester I SMP Negeri 1 Denpasar Tahun Pelajaran $2016 / 2017$
\end{abstract}

Kata kunci: mengungkapkan gagasan, konseling kelompok

\section{ABSTRACT}

The background of this study is the existence of a problem, namely the low ability to express ideas to students of class VIII A Semester I of SMP Negeri 1 Denpasar, so that these conditions can hinder the teaching and learning process in general. By knowing there are problems, the researchers want to overcome by carrying out research through group counseling, the purpose of this study is through group counseling can improve the ability to express ideas. This research was carried out in a cycle system, the results of the actions were monitored by observation and questionnaire. The results of monitoring are deformed descriptively. The evaluation results show that group counseling can improve the ability to express ideas. Based on the initial data is $52.50 \%$ to $75.00 \%$ after the first cycle was carried out, in the second cycle after the treatment improvement from the deficiencies found in the previous cycle increased to $97.50 \%$. in this second cycle has fulfilled the determined success indicators and the cycle was declared not continued, the conclusion of this study that group counseling can improve the ability to express ideas to students of class VIII A Semester I Denpasar 1 Public Middle School 2016/2017 Academic Year

Keywords: express ideas, group counseling 


\section{PENDAHULUAN}

Perkembangan zaman di dunia pendidikan yang terus berubah dengan signifikan sehingga banyak merubah pola pikir pendidik, dari pola pikir yang awam dan kaku menjadi lebih modern. Hal tersebut sangat berpengaruh dalam kemajuan pendidikan di Indonesia. Menyikapi hal tersebut pakar-pakar pendidikan mengkritisi dengan cara mengungkapkan dan teori pendidikan yang sebenarnya untuk mencapai tujuan pendidikan yang sesungguhnya.

$$
\text { Tujuan pendidikan adalah }
$$
menciptakan seseorang yang berkwalitas dan berkarakter sehingga memiliki pandangan yang luas kedepan untuk mencapai suatu cita- cita yang di harapkan dan mampu beradaptasi secara cepat dan tepat di dalam berbagai lingkungan. Karena pendidikan itu sendiri memotivasi diri kita untuk lebih baik dalam segala aspek kehidupan.

Karena dengan konseling kelompok masing-masing anggota dalam hal ini siswa dapat mengembangkan kemampuan berkemunikasi, menanggapi serta bertanya atau dalam hal mengemukakan gagasan lebih luas, karena konseling kelompok pada dasarnya adalah layanan konseling individual yang dilaksanakan didalam suasana kelompok. Disana ada konselor dan ada klien, yaitu para anggota kelompok (yang jumlahnya minimal dua orang). Disana terjadi hubungan konseling dalam suasana yang diusahakan sama seperti dalam konseling perorangan yaitu hangat, permisif, terbuka dan penuh keakraban, juga ada pengungkapan dan pemahaman masalah klien, penelusuran sebab-sebab timbulnya masalah, upaya pemecahan masalah (jika perlu dengan menerapkan metode-metode khusus), kegiatan evaluasi dan tindaklanjut.

Dengan demikian melalui layanan konseling kelompok dapat meningkatkan kemampuan mengungkapkan gagasan pada siswa kelas VIII A Semester I SMP Negeri 1 Denpasar Tahun Pelajaran 2016/2017. Tujuan penelitian ini adalah untuk mengetahui penggunaan layanan konseling kelompok dalam meningkatkan kemampuan mengungkapkan gagasan pada siswa kelas VIII SMP Negeri 1 Denpasar Tahun Pelajaran 2016/2017.

\section{METODE PENELITIAN \\ Setting/Lokasi Penelitian}

Sebagai upaya untuk meningkatkan kemampuan mengungkapkan gagasan siswa dalam proses pembelajaran, peneliti melakukan penelitian di SMP Negeri 1 Denpasar, Jalan Surapati No 2 Denpasar, Sekolah ini tempatnya strategis di pusat kota Denpasar, dan menjadi incaran masyarat dalam penerimaan peserta didik baru (PPDB) karena sekolah paporit dengan sekudang prestasi, tempat peneliti melaksanakan tugas sebagai guru pembimbing.

\section{Rancangan Penelitian}

Rancangan penelitian dalam penelitian tindakan kelas ini diadopsi dari seorang ahli yang mempergunakan model Kemmis dan Mc. Taggart (dalam Hamzah B. Uno dkk, 2011: 87) seperti pada gambar berikut. 


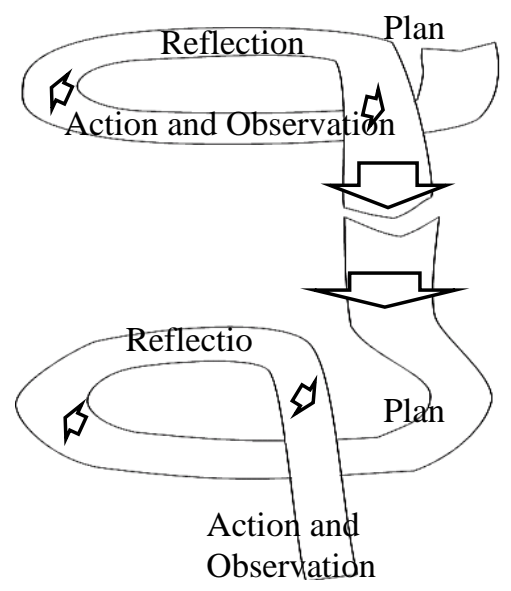

Gambar Desain PTK Model Kemmis dan Mc. Taggart (dalam Hamzah B. Uno dkk, 2011: 87)

\section{HASIL PENELITIAN DAN PEMBAHASAN}

\section{Hasil Penelitian}

\begin{abstract}
Berdasarkan Gambaran hasil penelitian ini dimulai dari mendeskripsikan data awal yang didapat, berlanjut dengan pemaparan tindakan siklus I dan siklus II dimulai dengan perencanaan, pelaksanaan, hasil observasi dan refleksi yang dilakukan terkait tahapan yang sudah dilakukan. hasil analisis data dan pembahasan yang telah disampaikan, dapat dipaparkan kesimpulan dari hasil pelaksanaan penelitian tindakan ini sebagai berikut.
\end{abstract}

\section{Deskripsi Awal}

Diperoleh gambaran dari data awal adalah banyaknya peserta didik yang komponen awalnya rendah yaitu 40 orang siswa (100\%). Hanya ada 21 orang siswa $(52,50 \%)$ yang mampu memperoleh keberhasilan sesuatu harapan. Hal ini merupakan ciri bahwa sebagian anak masih membutuhkan solusi dan cara mengatasi secara serius untuk dapat meningkatkan perkembangan kemampuan megungkapkan gagasan mereka.

\section{Deskripsi Siklus I \\ Perencanaan I}

Perencanaan Siklus I disusun sedemikian rupa untuk merancang cara membantu peserta didik mampu meningkatkan kemampuan mengungkapkan gagasan. Adapun persiapan yang direncanakan yaitu:

1. Menyusun jadwal kegiatan pelaksanaan penelitian.

2. Menyusun rencana pelaksanaan layanan (RPL).

3. Membicarakan hal-hal penting bersama teman-teman guru seprofesi, langkah-langkah yang bisa membantu peningkatan kemampuan mengungkapkan gagasa, merencanakan layanan yang paling tepat untuk digunakan dalam mengatasinya.

4. Menyusun format penilaian.

5. Menyiapkan bahan-bahan pendukung layanan.

6. Merancang skenario layanan da lagkah-lagkah konseling kelompok.

\section{SIKLUS I}

1. Banyak kelas $(\mathrm{K})=1+3,3 \times \operatorname{LOG}(\mathrm{N})$

$$
\begin{aligned}
& =1+3,3 \times \log 40 \\
& =1+(3,3 \times 1,60) \\
& =1+5,28=6,28 \rightarrow 6
\end{aligned}
$$

2. Rentang kelas $(r)=$ skor maksimum skor minimum $\quad=93-50$

$$
=43
$$

3. Panjang kelas interval (i) $=\frac{r}{K}=\frac{43}{6}=$ $7,17 \rightarrow 8$

4. Data Interval Kelas 
Tabel 4. Data Interval Kelas Siklus I

\begin{tabular}{ccccc}
\hline $\begin{array}{c}\text { No } \\
\text { Urut }\end{array}$ & Interval & $\begin{array}{c}\text { Nilai } \\
\text { Tengah }\end{array}$ & $\begin{array}{c}\text { Frekuensi } \\
\text { Absolut }\end{array}$ & $\begin{array}{c}\text { Frekuensi } \\
\text { Relatif }\end{array}$ \\
\hline 1 & $50-57$ & 53,5 & 10 & 25,00 \\
\hline 2 & $58-65$ & 61,5 & 0 & 0,00 \\
\hline 3 & $66-73$ & 69,5 & 0 & 0,00 \\
\hline 4 & $74-81$ & 77,5 & 7 & 17,50 \\
\hline 5 & $82-89$ & 85,5 & 18 & 45,00 \\
\hline 6 & $90-97$ & 93,5 & 5 & 12,50 \\
\hline & Total & 40 & 100 \\
\hline
\end{tabular}

\section{Sintesis}

Sintesis yang dapat disampaikan adalah ada 30 orang siswa dari 40 orang siswa yang ditulis memperoleh nilai diatas kreteria yang baik, dan ada 10 orang siswa $(25 \%)$ masih dibawak kreteria baik, siswa yang tergolong belum mampu memenuhi pencapaian keberhasilan pada siklus I ini. Dari data yang diperoleh dapat diberikan sintesis bahwa usulan keberhasilan pada siklus I belum terpenuhi.

\section{Penilaian Siklus I}

Sesuai fakta yang berhasil ditemui di lapangan, pada Siklus I ini ditemukan bebearpa kekurangan-kekurangan dan kelebihan-kelebihan yang mesti dijabarkan.

\section{Kekurangan-kekurangan yang ada:}

1. Pelayanan belum maksimal sehingga konsentrasi peserta didik belum sesuai harapan.

2. Peneliti kurang memberikan waktu yang lebih lama bagi siswa dalam proses konseling kelompok untuk mengentaskan permasalahan.

3. Suasana layanan konseling kelompok kurang menarik, beberapa siswa memang menginginkan suasana yang menyenangkan.

4. Peneliti belum memahami betul kondisi peserta didik pendekatan yang digunakan.

\section{Kelebihan yang ada adalah:}

a). Peneliti berupaya menyiapkan segala sesuatunya agar proses konseling kelompok dapat berjalan lancar.

b). Pengelolaan waktu sudah diupayakan maksimal.

c). Validasi instrumen telah diupayakan lewat membicarakannya dengan teman seprofesi.

d) Konsultasi dengan teman seprofesi telah dilakukan setelah melakukan proses konseling. Kelompok

\section{Deskripsi Siklus II}

\section{Perencanaan II}

Mengacu pada kelemahan-kelemahan yang masih ada pada siklus I maka dilaksanakan::

1. Melakukan analisis karakteristik siswa yang telah dijadikan subjek penelitian dan mengkaji secara seksama kendala dan alternatif tindakan yang dapat digunakan untuk mengatasinya.

2. Melakukan pengecekan mengenai jadwal pelaksanaan penelitian yang telah direncakan.

3. Menyusun secara rinci skenario tindakan yang telah direncakan dan melakukan pengkajian ulang untuk meminimalisir kemungkinan terjadinya kesalahan.

4. Berkonsultasi dengan teman-teman guru tentang konseling kelompok 


\section{Pelaksanaan II}

Pelaksanaan Silkus II difokuskan lebih banyak pada peserta didik yang masih rendah kemampuan mengungkapkan gagasannya,dengan menyempurnakan pelaksanaan kegiatan konseling kelompok dengan menumbuhkan dinamika di dalam kelompok sehingga tetap menarik dan termotivasi untuk meningkatkan kemampuan mengungkapkan gagasan bagi peserta didik yang masih rendah seperti:

1. Tahap pembentukan

a). Menerima secara terbuka dan mengucapkan terima kasih

b). Berdoa

c). Menjelaskan pengertian konseling kelompok

d). Menjelaskan tujuan konseling kelompok

e). Menjelaskan cara pelaksanaan konseling kelompok

f). Menjelaskan azas-azas konseling kelompok

2. Tahap peralihan

a). Menjelaskan kembali kegiatan konseling kelompok

b). Tanya jawab kesiapan anggota untuk kegiatan lebih lanjut

c). Mengenali suasana apabila anggota secara keseluruhan sebagian belum siap untuk memasuki tahap berikutnya dan mengatasi suasana tersebut.

3. Tahap kegiatan

a). Menjelaskan masalah pribadi yang hendaknya dikemukakan oleh anggota kelompok b). Mempersilakan anggota untuk mengemukakan masalah pribadi masing-masing secara bergantian.

c). Memilih/menetapkan masalah yang dibahas dalam penelitian ini adalah masalah kemampuan mengungkapkan gagasan

d). Membahas masalah yang dipilih secara tuntas

e). Selingan

f). Menegaskan komitmen anggota yang masalahnya telah dibahas (apa yang akan dilakukan berkenaan adanya pembahasan demi terentaskan masalahnya)

4. Tahap pengakhiran

a). Menjelaskan bahwa kegiatan konseling kelompok akan diakhiri

b). Anggota memberikan kesan dan menilai kemajuan yang dicapai masing-masing

c). Pembahasan kegiatan lanjutan

d). Pesan serta tanggapan anggota

e). Ucapan terima kasih

f). Berdoa

g). Perpisahan

\section{Pengamatan/Observasi II}

Pelaksanaan pengumpulan data dilakukan mengacu pada kriteria penilaian yang telah ditetapkan. Upaya keras guru untuk melatih keberanian anak, meningkatkan kepercayaan diri, dan mengokohkan jalinan persahabatan terus dilakukan dengan giat sambil mengamati keadaan anak-anak, mencek perkembangan kemampuan mereka, memantau sikap mental mereka dan mencek perubahan yang terjadi.

Hasil observasi yang dilakukan pada siklus II ini dapat dijelaskan sebagai berikut.

\begin{tabular}{lc}
\hline Jumlah nilai & 3404 \\
\hline Rata-rata (Mean) & 85.10 \\
\hline Kreteria kemampuan mengungkapkan gagasan yang baik & 80 \\
\hline $\begin{array}{l}\text { Jumlah siswa yang kemampuan mengungkapkan gagasan yang } \\
\text { kurang dan sangat kurang }\end{array}$ & 1 \\
\hline \hline
\end{tabular}


sudah baik

Prosentase siswa kemampuan mengungkapkan gagasan yang baik $\quad 97,50 \%$

Prosentase Komitmen yang baik $=$

Jmlh siswa yang kemampuan mengungkapkan gagasan yang baik x $100 \%$

Jumlah siswa

$$
\begin{aligned}
& =\frac{39 \times 100 \%}{40} \\
& =97,50 \% \\
& \text { Catatan }
\end{aligned}
$$

Menurut Sutrisno Hadi, 2000: 17

Kreteria penilaian 80 - $90=$ Baik

berarti kriteria Kometmen yang baik adalah $80-90$

Tabel di atas menunjukkan hasil observasi rendahnya kemampuan mengungkapkan gagasan dalam proses belajar di di kelas selama pemantauan dalam beberapa hari setelah dilaksanakan siklus II telah terjadi peningkatan mencapai $97,50 \%$ atau ada 39 orang. siswa dari 40 orang siswa sudah mencapai baik setelah digunakan konseling kelompok dengan menyempurnakan proses dan langkah-langkah dari pada konseling kelompok.

\section{Refleksi}

Sesuai pendapat ahli yang sudah disampaikan pada refleksi Siklus I bahwa dalam melakukan refleksi yang perlu disampaikan adalah: membuat analisis, sintesis dan penilaian. Untuk hal tersebut disampaikan lengkapnya seperti berikut.

\section{Sintesis}

Sesuai pendapat-pendapat ahli maupun pandangan-pandangan yang dikemukakan oleh Depdiknas yang telah disampaikan pada analisis di Siklus I tentang cara menulis analisis deskriptif, maka pada Siklus II ini ini disampaikan hal-hal berikut:

Hasil yang diperoleh dari pemberian instrumen observasi kemampuan mengungkapkan gagasan adalah dari 40 orang siswa, 39 orang siswa (97,50\%) memperoleh nilai diatas kreteria baik, kemampuan mengungkapkan gagasan siswa tersebut sudah ada peningkatan, ini artinya sudah berhasil sesuai tuntutan indikator serta sudah meningkat sesuai harapan. Ada lagi 1 orang $(2,50 \%)$ siswa yang kemampuan mengungkapkan gagasan masih rendah artinya bahwa sudah mencapai keberhasilan minimal yang dituntut, bahwa indikator keberhasilan penelitian yang diharapkan sudah dapat dicapai.

Selanjutnya karena data yang diperoleh adalah data dalam bentuk angka maka dilanjutkan dengan analisis kuantitatif sebagai berikut:

1. Rata-rata (mean) dihitung dengan: $\frac{\text { Jumlah nilai }}{\text { Jumlah siswa }}=\underline{3397}=84.93$

2. Median (titik tengahnya) dicari dengan mengurut data/nilai siswa dari yang terkecil sampai terbesar. Setelah diurut apabila jumlah data ganjil maka mediannya adalah data yang ditengah. Kalau jumlahnya genap maka dua data yang di tengah dijumlahkan dibagi 2 (dua). Untuk median yang diperoleh dari data siklus I dengan menggunakan cara tersebut adalah:

1. Modus (angka yang paling banyak/paling sering muncul) setelah 
diasccending/diurut angka tersebut adalah: 85

2. Untuk persiapan penyajian dalam bentuk grafik maka hal-hal berikut dihitung terlebih dahulu.

\section{SIKLUS II}

$$
\begin{aligned}
& =1+3,3 \times \log 40 \\
& =1+(3,3 \times 1,60) \\
& =1+5,28=6,28 \rightarrow 6
\end{aligned}
$$

2. Rentang kelas $(\mathrm{r})=$ skor maksimum skor minimum $=93-74=19$

3. Panjang kelas interval (i) $=$

$$
\frac{r}{K}=\frac{19}{6}=3,17 \rightarrow 4
$$

\begin{tabular}{|c|c|c|c|c|}
\hline No & \multirow{2}{*}{ Interval } & Nilai & Frekuensi & Frekuensi \\
\hline Urut & & Tengah & Absolut & Relatif \\
\hline 1 & $74-77$ & 75,5 & 1 & 2,50 \\
\hline 2 & $78-81$ & 79,5 & 0 & 0,00 \\
\hline 3 & $82-85$ & 83,5 & 30 & 75,00 \\
\hline 4 & $86-89$ & 87,5 & 0 & 0,00 \\
\hline 5 & $90-93$ & 91,5 & 9 & 22,50 \\
\hline 6 & $94-97$ & 95,5 & 0 & 0,00 \\
\hline otal & & & 40 & 100 \\
\hline
\end{tabular}

4. Data Interval Kelas

1. Banyak kelas $(\mathrm{K})=1+3,3 \times$ LOG $(\mathrm{N})$

Tabel 4. Data Interval Kelas Siklus II

\section{P E N U T U P}

\section{Simpulan}

Dari frekuensi hasil yang diperoleh dari penelitian berdasarkan analisis semua kegiatan yang telah dilaksanakan baik pelaksanaan awal, pelaksanaan siklus I maupun pelaksanaan siklus II berikut semua hasil-hasil yang telah diperoleh dapat disampaikan kesimpulannya sebagai berikut:

1. Perhatian utama yang akan dibahas dari penelitian ini adalah untuk membuktikan apakah konseling kelompok dapat meningkatkan kemampuan mengungkapkan gagasan peserta didik? Dari hasi analisis yang telah dilakukan yang dilanjutkan dengan pembahasan dapat disampaikan bahwa peningkatan kemampuan mengungkapkan gagasan dapat digambarkan: Dari data awal layanan konseling kelompok dalam mengatasi siswa yang rendah kemampuan mengungkapkan gagasan mengalami peningkatan tiap siklusnya yaitu pada awalnya kemampuan mengungkapkan gagasan yang baik adalah 21 orang siswa, dari 40 orang peserta didik, kemudian dilaksanakan siklus I meningkat menjadi 30 orang dan dilanjutkan pelaksanaan siklus II maka mencapai 39 orang.

2. Fakta-fakta di atas yang dibarengi dengan penyajian data hasil observasi baik siklus I maupun siklus II yang disampaikan pada Bab IV telah dapat dibuktikan bahwa dengan layanan konseling kelompok dapat meningkatkan kemampuan mengungkapkan gagasannya siswa dalam belajar di kelas. Dengan hasil tersebut dapat dibuktikan bahwa rumusan masalah dan tujuan penelitian telah tercapai dan hipotesis yang diajukan sudah dapat diterima. Untuk 
hal tersebut selanjutnya perlu disampaikan saran.

\section{DAFTAR PUSTAKA}

Arikunto, Suharsimi. 1999. Prosedur Penelitian Suatu Pendekatan Praktek. Jakarta: Rineka Cipta.

Depdiknas RI. 2003. Undang Undang No 20 Tentang Sistem Pendidikan Nasional (SISDIKNAS) Jakarta: Depdiknas.

Depdiknas RI. 2003. Bidang Bidang BK $G P B$ - 03. Jakarta: Dirjen Dikdasmen.

Jenis Jenis Layanan $B K G P B$ - 04. Jakarta: Dirjen Dikdasmen.

.Pemberian Layanan

Bantuan Siswa - GBI 09. Jakarta: Dierjen Dikdasmen.

Djumhur, Muhammad, S. (1975). Bimbingan dan Konseling di Sekolah. Bandung: CV Ilmu.

Maidar G.Arsjad 1991 Pembinaan Kemampuan Berbicara Bahasa Indonesia, Cetakan Kedua Jakarta: Erlangga

Nurkancana,Wayan Sumartana. (1992). Evaluasi Pendidikan. Surabaya: Usaha Nasional.

Nurihsan, Juntika, Ahmad. (2007). Bimbingan dan Konseling. Bandung: Refika Aditama.

Prayitno, Ermin AMTI. 1975. Dasar Dasar Bimbingan dan Konseling. RI: Jakarta.

Prayitno, 1995 Layanan Bimbingan dan Konseling (Dasar dan Profil) Ghalia Indonesia: Buku Seri Bimbingan dan Konseling di Sekolah

Sugiyono. (2002). Metode Penelitian Administrasi. Bandung: $\mathrm{CV}$. Alfabeta.

Sukmadinata, Sayaodih, Nana. 2005. Landasan Psikologi Proses Pendidikan. Bandung: PT Remaja Rosdakarya.

\section{Suryobroto, $\quad$ S.1984. Psikologi Perkembangan Edisi IV Cetakan I. Yogyakarta: Rake Press.}

Walgito, Bimo. 2004. Bimbingan Konseling di Sekolah. Yogyakarta: PT.Andi. 